\title{
The effects of different amounts and types of fat on milk fatty acid composition in sheep ${ }^{*}$
}

\author{
A. Potkański' ${ }^{1}$ M. Szumacher-Strabel ${ }^{1}$, J. Kowalczyk ${ }^{2}$, \\ A. Cieślak ${ }^{1}$ and M. Czauderna ${ }^{2}$
}

\author{
'Department of Animal Nutrition and Feed Management, \\ August Cieszkowski Agricultural University \\ Wotyńska 33, 60-637 Poznań, Poland \\ ${ }^{2}$ The Kielanowski Institute of Animal Physiology and Nutrition, \\ Polish Academy of Sciences \\ 05-11- Jablonna, Poland
}

\begin{abstract}
Four milking ewes $(50 \pm 5 \mathrm{~kg})$ were used in a $4 \times 4$ Latin square experiments to determine the effects of different sources and amounts of vegetable-origin fat in the diet on the fatty acid composition of milk. Ewes of the control group were fed a diet consisting of meadow hay and concentrate (60:40) that was supplemented for the experimental groups with rape seed oil, hydrogenated rape seed oil, or linseed oil at a level 4,8 or $10 \%$ in dry matter of the diet. Addition of linseed and rape seed oil to the diet decreased $(\mathrm{P}<0.05, \mathrm{P}<0.01)$ the level of total saturated fatty acids in milk. Rape secd oil and hydrogenated rape seed oil caused significant $(\mathrm{P}<0.05, \mathrm{P}<0.01)$ increases in the level of mono-unsaturated fatty acids, whereas significant differences were not reached $(P>0.05)$ when linseed oil was fed to sheep. Also, the total amount of PUFA+MUFA increased in milk $(\mathrm{P}<0.05, \mathrm{P}<0.01)$ when dicts with linseed and rape seed oil were fed. The level of stearic acid differed depending on the added fat. A lower $(\mathrm{P}<0.01)$ level of stearic acid was observed when $8 \%$ of linseed oil was added, whereas it was higher $(\mathrm{P}<0.05)$ when $10 \%$ of linseed oil and $8 \%$ and $10 \%$ of rape seed oil were added to the ration. Fecding ruminants rations supplemented with fat of vegetable origin increased the energy content of the diet and also improved the level of desirable fatty acids in milk, e.g., MUFA and PUFA, which may be recommended in the treatment of some diseases.
\end{abstract}

KEY WORDS: sheep, fat, fatty acids, MUFA, PUFA, milk

* Supported by the State Committee for Scientific Research, Grant No. 5 PO6E 01119 


\section{INTRODUCTION}

The purpose of modifying animal origin fats is to produce high quality products meeting dietary recommendations for a reduced intake of saturated fatty acids (SFA) and an increased intake of mono- (MUFA) and polyunsaturated (PUFA) fatty acids in the human diet (Jakobsen, 1999). Consuming such enriched products lowers the risk of obesity, cancer, diabetes, and cardiovascular diseases (Grundy, 1999; Voigt and Hagemeister, 2001). Breeding for milk quality is a long-term process and there is always the risk that market demand will have changed by the time the target milk quality has been met. Manipulating milk quality through nutritional changes is the best option. During lactation, the ability to produce large quantities of milk exceeds the capacity of cows to consume enough feed to meet their needs for energy, causing a negative energy balance (Bremmer et al., 1998). Supplementing diets for high producing ruminants with fat helps to overcome limitations in energy supplies and to increase the marketable attributes of their products. Literature data indicates that acceptable fatty acid profiles do not require extreme changes in the fatty acid composition of milk. The aim of the conducted experiments was to determine the effects of different fat sources and amounts in the diet on the fatty acid composition of ewe milk.

\section{MATERIAL AND METHODS}

\section{Animals and diets}

Four lactating ewes $(50 \pm 5 \mathrm{~kg})$ were used in $4 \times 4$ Latin square experiments. Three experiments examined how milk fatty acid composition was altered by dietary fats differing in fatty acid concentration: rape seed oil, hydrogenated rape seed oil and linseed oil. In all experiments fat was added to rations that consisted of meadow hay and concentrate $(60: 40 \%)$ at $0,4,8$ and $10 \%$ in dry matter of the diet. The energy value of the rations was $1.21 \mathrm{JPM}$, whereas the crude protein content was BTJN $120 \mathrm{~g}$ and BTJE $129 \mathrm{~g} / \mathrm{kg}$. The ewes were milked twice daily at 0800 and 1700 , and yields were recorded. Sheep had free access to water and were fed twice daily following each milking. All diets were formulated with wheat meal, soyabean meal, wheat bran and minerals (Table 1).

\section{Sampling and analysis}

Feeds were sampled weekly throughout the experiment. The experiment consisted of four 16-day trials (12 days of adaptation to the diet, the last four for sample collection). During the four-day sample collection time, milk samples were 
TABLE 1

Composition of the diet, $\%$

\begin{tabular}{lrrrr}
\hline \multirow{2}{*}{ Components } & \multicolumn{4}{c}{ Level of added fat } \\
\cline { 2 - 5 } & $0 \%$ & $4 \%$ & $8 \%$ & $10 \%$ \\
\hline Meadow hay & 59.0 & 57.0 & 55.0 & 54.0 \\
Wheat meal & 21.0 & 20.0 & 19.0 & 19.0 \\
Rapeseed meal & 3.0 & 3.0 & 3.0 & 3.0 \\
Wheat bran & 15.0 & 14.0 & 13.0 & 12.0 \\
Minerals & 2.0 & 2.0 & 2.0 & 2.0 \\
Fat & - & 4.0 & 8.0 & 10.0 \\
\hline
\end{tabular}

collected twice daily. Total fatty acid content and composition of milk fat were determined according to the procedures of Heinig et al. (1998), modified by Czauderna et al. (2001).

Statistical analysis

All of the data were analyzed using SAS procedures (User's Guide, 1990).

\section{RESULTS}

The results of the experiments confirm the possibility that the fatty acid content of sheep milk can be manipulated by the diet. The addition of linseed (Table 2 ) and

TABLE 2

Fatty acid composition of milk fat from ewes fed diets supplemented with linseed oil, $\%$

\begin{tabular}{|c|c|c|c|c|c|c|c|c|}
\hline \multirow{2}{*}{ Linseed oil } & \multicolumn{2}{|c|}{$0 \%$} & \multicolumn{2}{|c|}{$4 \%$} & \multicolumn{2}{|c|}{$8 \%$} & \multicolumn{2}{|c|}{$10 \%$} \\
\hline & mean & $\mathrm{CV}$ & mean & $\mathrm{CV}$ & mean & $\mathrm{CV}$ & mean & $\mathrm{CV}$ \\
\hline Miristic acid & $9.3^{\mathrm{A}}$ & 15.7 & 6.3 & 17.00 & $3.5^{\mathrm{A}}$ & 76.2 & 6.2 & 31.8 \\
\hline Palmitic acid & $32.9^{\mathrm{BCa}}$ & 19.0 & $18.5^{\mathrm{Bb}}$ & 5.09 & $8.9^{\mathrm{ACb}}$ & 136.2 & $22.7^{\mathrm{Aa}}$ & 17.3 \\
\hline Caprylic acid & 2.4 & 8.4 & 2.0 & 3.58 & 0.9 & 40.3 & 1.2 & 9.5 \\
\hline Lauric acid & 2.7 & 15.5 & 3.2 & 28.89 & 0.8 & 128.6 & 1.7 & 33.8 \\
\hline Stearic acid & $9.0^{\mathrm{B}}$ & 12.6 & 10.3 & 17.11 & $8.1^{\mathrm{A}}$ & 64.1 & $16.3^{\mathrm{AB}}$ & 20.6 \\
\hline Total SFA & $56.3^{\mathrm{Ab}}$ & 12.8 & $40.3^{\mathrm{ab}}$ & 2.63 & $22.1^{\wedge a}$ & 96.2 & 48.0 & 9.9 \\
\hline Total MUFA & 39.8 & 12.0 & 56.9 & 3.29 & 48.7 & 25.8 & 21.5 & 25.8 \\
\hline Total PUFA n-3 & 0.7 & 31.3 & 0.8 & 2.70 & 1.3 & 40.6 & 1.2 & 25.7 \\
\hline Total PUFA n-6 & 3.2 & 70.0 & 2.9 & 26.72 & 4.7 & 57.4 & 1.8 & 50.8 \\
\hline \multicolumn{9}{|l|}{ Total PUFA } \\
\hline + MUFA & $43.7^{\mathrm{Bb}}$ & 13.3 & $60.6^{\mathrm{ab}}$ & 2.82 & $54.7^{\mathrm{ABa}}$ & 26.3 & $51.1^{\mathrm{A}}$ & 24.4 \\
\hline
\end{tabular}

means in rows with the same letter differ statistically significant ${ }^{A, B, C}-\mathrm{P}<0.01 ;{ }^{\text {a.b.c. }}-\mathrm{P}<0.05$ 
rape seed oil (Table 3$)$ to the sheep diet resulted in a decrease in total SFA $(\mathrm{P}<0.05$, $\mathrm{P}<0.01)$ in all experimental groups receiving added fat. Hydrogenated rape seed oil (Table 4) had no influence on total SFA content, although a decreasing tendency was also observed. Rape seed oil and hydrogenated rape seed oil caused a significant $(\mathrm{P}<0.05, \mathrm{P}<0.01)$ increase in the MUFA level, whereas it was unchanged when linseed oil was fed to sheep. Also total PUFA and MUFA were increased $(\mathrm{P}<0.05, \mathrm{P}<0.01)$ when linseed and rape seed oil were added to sheep

TABLE 3

Fatty acid composition of milk fat from ewes fed diets supplemented with rape seed oil, \%

\begin{tabular}{|c|c|c|c|c|c|c|c|c|}
\hline \multirow{2}{*}{ Rape seed oil } & \multicolumn{2}{|c|}{$0 \%$} & \multicolumn{2}{|c|}{$4 \%$} & \multicolumn{2}{|c|}{$8 \%$} & \multicolumn{2}{|c|}{$10 \%$} \\
\hline & mean & $\mathrm{CV}$ & mean & $\mathrm{CV}$ & mean & $\mathrm{CV}$ & mean & $\mathrm{CV}$ \\
\hline Miristic & $10.5^{\mathrm{Aab}}$ & 28.1 & $7.7^{\mathrm{b}}$ & 19.1 & $6.7^{\mathrm{A}}$ & 6.5 & $7.0^{\mathrm{a}}$ & 8.9 \\
\hline Palmitic & $32.6^{\mathrm{ABC}}$ & 9.9 & $23.5^{\mathrm{B}}$ & 10.4 & $19.0^{\mathrm{C}}$ & 12.8 & $20.9^{\mathrm{A}}$ & 30.7 \\
\hline Caprylic & 2.1 & 35.6 & 1.5 & 43.7 & 1.2 & 11.2 & 1.2 & 21.7 \\
\hline Lauric & 3.2 & 44.2 & 2.1 & 32.2 & 1.8 & 9.7 & 1.9 & 10.6 \\
\hline Stearic & $8.7^{\mathrm{ab}}$ & 17.6 & 11.2 & 15.6 & $12.9^{a}$ & 12.8 & $12.8^{b}$ & 8.6 \\
\hline Total SFA & $57.1^{\mathrm{AB}}$ & 11.2 & 46.0 & 6.9 & $41.5^{\mathrm{B}}$ & 4.1 & $43.8^{\mathrm{A}}$ & 15.1 \\
\hline Total MUFA & $39.5^{\mathrm{ABC}}$ & 17.6 & $51.3^{\mathrm{B}}$ & 8.6 & $55.4^{\mathrm{C}}$ & 3.9 & $53.5^{\wedge}$ & 12.9 \\
\hline Total PUFA n-3 & 0.5 & 8.9 & 0.5 & 35.1 & l.1 & 120.9 & 0.5 & 19.4 \\
\hline Total PUFA n-6 & 2.9 & 56.0 & 2.2 & 49.0 & 2.1 & 45.1 & 2.3 & 36.4 \\
\hline \multicolumn{9}{|l|}{ Total PUFA } \\
\hline + MUFA & $42.9^{\mathrm{Aßa}}$ & 14.9 & $54.0^{\mathrm{a}}$ & 5.9 & $58.6^{\mathrm{B}}$ & 2.9 & $56.2^{\mathrm{A}}$ & 11.7 \\
\hline
\end{tabular}

means in rows with the same letter differ statistically significant ${ }^{\wedge . B . C}-\mathrm{P}<0.01 ;{ }^{\text {a.b.s }}-\mathrm{P}<0.05$

TABLE 4

Fatty acid composition of milk fat from ewes fed diets supplemented with hydrogenated rape seed oil, \%

\begin{tabular}{|c|c|c|c|c|c|c|c|c|}
\hline \multirow{2}{*}{$\begin{array}{l}\text { Hydrogenated } \\
\text { rape seed oil }\end{array}$} & \multicolumn{2}{|c|}{$0 \%$} & \multicolumn{2}{|c|}{$4 \%$} & \multicolumn{2}{|c|}{$8 \%$} & \multicolumn{2}{|c|}{$10 \%$} \\
\hline & mean & $\mathrm{CV}$ & mean & $\mathrm{CV}$ & mean & $\mathrm{CV}$ & mean & $\mathrm{CV}$ \\
\hline Miristic & $9.9^{\mathrm{ad}}$ & 17.1 & $9.0^{\mathrm{bc}}$ & 19.9 & $6.3^{\mathrm{ed}}$ & 19.2 & $6.0^{\mathrm{ab}}$ & 30.1 \\
\hline Palmitic & $25.9^{\mathrm{abc}}$ & 5.4 & 23.2 & 8.9 & $19.1^{\mathrm{bc}}$ & 11.3 & $18.5^{a}$ & 9.9 \\
\hline Stearic & 10.4 & 23.8 & 10.2 & 12.9 & 11.9 & 8.4 & 12.2 & 29.7 \\
\hline Total SFA & 46.1 & 6.5 & 42.4 & 18.8 & 37.3 & 10.2 & 36.6 & 12.3 \\
\hline Total MUFA & $49.5^{\mathrm{ab}}$ & 7.3 & 54.1 & 6.5 & $59.4^{b}$ & 6.3 & $60.1^{\mathrm{a}}$ & 8.3 \\
\hline Total PUFA n-3 & 0.4 & 102.6 & 0.3 & 80.4 & 0.4 & 65.0 & 0.3 & 72.3 \\
\hline Total PUFA n-6 & 4.1 & 16.7 & 3.3 & 12.7 & 2.9 & 45.5 & 2.9 & 50.6 \\
\hline \multicolumn{9}{|l|}{ Total PUFA } \\
\hline + MUFA & 53.9 & 5.7 & 57.3 & 6.6 & 62.7 & 6.1 & 63.4 & 7.1 \\
\hline
\end{tabular}

means in rows with the same letter differ statistically significant ${ }^{A . B}, C_{-} P<0.01 ;{ }^{a, b, c}-\mathrm{P}<0.05$ 
rations. The concentration of miristic and palmitic acids was lower in the milk of all sheep in the experimental groups $(\mathrm{P}<0.05, \mathrm{P}<0.01)$, regardless of the type and amount of supplemented fat. The level of stearic acid differed depending on the added fat. A lower $(\mathrm{P}<0.01)$ level of stearic acid was observed when $8 \%$ of linseed oil was added, whereas higher $(\mathrm{P}<0.05)$, when $10 \%$ of linseed oil and 8 and $10 \%$ of rape seed oil were added to the ration.

\section{DISCUSSION}

Ruminant fat is an important part of the human diet in many countries, particularly milk fat, which represents up to $75 \%$ of the total consumption of fat from ruminants and up to $25-35 \%$ of total saturated fat (Chilliard et al., 2000). Milk fatty acids, such as oleic acid and polyunsaturated fatty acids (especially n-3), have a potential antiatherogenic or anticarcinogenic role, but some saturated fats also have a potential negative effect on human health. It is now clear that it is mainly lauric, myrictic and palmitic fatty acids that are responsible for increasing plasma total and LDL cholesterol concentrations, while the other major SFA, stearic acid, has been shown not to increase total cholesterol or LDL-cholesterol (Williams, 2000). Linseed oil, rape seed oil, as well as hydrogenated rape seed oil added to sheep diets decreased the level of undesirable fatty acids.

Also in the experiment carried out by Brzóska et al. (1998) the addition of vegetable-origin fat to diets significantly decreased the concentration of saturated acids in milk. During the last 20 years, intensive research has been conducted to increase the content of unsaturated fatty acids in milk fat (Wagner et al., 1998). According to Coppock and Wilks (1991) supplemental dietary fat changes the fatty acid composition of milk and in some cases it may suppress milk fat yield. In experiments carried out by adding rape seed oil and hydrogenated rape seed oil, MUFA levels increased in milk, as did total PUFA+MUFA when linseed and rape seed oil were added to sheep rations. DePeters et al. (2001) reported that canola oil treatments decreased the palmitic acid content and increased the oleic acid content of milk fat compared with the control.

Recently, there has been increased focus on a nutritional approach to both the prevention and cure of many diseases (Sasaki, 2000). Feeding fat of vegetable origin in ruminant rations increases the energy content of their diet and also improves the level of desirable nutrients, e.g., MUFA and PUFA, which may be beneficial in the treatment of some diseases. 


\section{REFERENCES}

Bremmer D.R., Ruppert L.D., Clark J.H., Drackley J.K., 1998. Effects of chain length and unsaturation of fatty acid mixtures infused into the abomasums of lactating dairy cows. J. Dairy Sci. 81, 176-188

Brzóska F., Gąsior R., Brzóska B., Zyzak W., 1998. Modification of the fatty acid profile of cows milk for human needs by feeding Ca-fatty acid salt of linseed or fish oil. Book of Abstracts of the $49^{\text {th }}$ Annual Meeting of EAAP, Warsaw (Poland), p. 84 (Abstr. N5.2)

Chilliard Y., Ferlay A., Mansbridge R.M., Doreau M., 2000. Ruminant milk fat plasticity: nutritional control of saturated, polyunsaturated, trans and conjugated fatty acids. Ann. Zootech. $49,181-205$

Coppock C.E., Wilks D.L., 1991. Supplemental fat in high-energy rations for lactating cows. Effects on intake, digestion, milk yield and composition. J. Anim. Sci. 69, 3826-3837

Czauderna M., Kowalczyk J., Potkański A., Szumacher-Strabel M., Chojecki G., 2001. Quantification of conjugated Jinoleic acid and other essential fatty acids in ovine meat, milk, fat and intestinal digesta. J. Anim. Feed Sci. 10, Suppl. 2, 385-392

DePeters E.J., German J.B., Taylor S.J., Essex S.T., Perez-Monti II, 2001. Fatty acid and triglyceride composition of milk fat from lactating Holstein cows in response to supplemental canola oil. J. Dairy Sci. 84, 929-936

Grundy S.M., 1999. The optimal ratio of fat to carbohydrate in the dict (Review). Ann. Rev. Nutr. $19,325-341$

Heinig K., Hissner F., Martin S., Vogt C., 1998. Separation of saturated and unsaturated fatty acids by capillary electrophoresis and HPLC. Amer. Lab., May, 24-29

Jakobsen K., 1999. Dietary modifications of animal fats: status and future perspectives. Fett-Lipid $101,475-483$

SAS ${ }^{k,}, 1990$. SAS/STAT Users Guide (Release 6.03). SAS institute Inc., Cary, NC (USA)

Sasaki T., Kanke Y., Kudoh K., Nagahashi M., Toyokawa M., Matsuda M., Shimizu J., Takita T., 2000. Dietary $n-3$ polyunsaturated fatty acid and status of immunocompetent cells involved in innate immunity in female rats. Ann. Nutr. Metab. 44, 38-42

Voigt J., Hagemeister H., 2001. Dictary influence on a desirable fatty acid composition in milk from dairy cattle. J. Anim. Feed Sci. 10, Suppl. 1, 87.103

Wagner K., Aulrich K., Leibzien P., Flachowsky G., 1998. Research note: Effect of duodenal infused unsaturated fatty acids on dairy milk composition. Arch. Anim. Nutr. 51, 349-354

Williams C.M., 2000. Dietary fatty acids and human health. Ann. Zootech. 49, 165-180 


\section{STRESZCZENIE}

\section{Wplyw dodatku thuszczu na skład kwasów tluszczowych mleka owiec}

Głównym celem modyfikowania składu kwasów tłuszczowych w mleku zwicrząt przcżuwających jest obniżenie poziomu nasyconych kwasów tłuszczowych (głównie mirystynowego, laurynowego i palınitynowego) oraz zwiçkszenie ilości jedno- i wielonienasyconych kwasów t\}uszczowych. W przeprowadzonych doświadezeniach materiał doświadczalny stanowiły cztery owce mleczne o średniej masie ciała $50 \pm 5 \mathrm{~kg}$, na których badano wpływ dodatku tłuszczu do diety składającej się z siana i micszanki treściwej $(60: 40 \%)$ na zawartość kwasów tłuszczowych w mleku. Przeprowadzono trzy doświadczenia, w układzie kwadratu lacińskiego $4 \times 4$. Dodatek tluszczu stanowił olej rzcpakowy, uwodorniony olej rzepakowy oraz olej lniany podawane w ilości $0,4,8$ i $10 \%$ suchej masy dawki. Oznaczono poziom i skład kwasów tłuszczowych w mleku. Dodatek oleju lnianego i rzepakowego obnizył $(\mathrm{P}<0,05 ; \mathrm{P}<0,01)$ poziom nasyconych kwasów thuszczowych w mleku owiec, natomiast dodatek oleju rzepakowego oraz uwodomionego oleju rzepakowego spowodował wzrost $(\mathrm{P}<0,05 ; \mathrm{P}<0,01)$ poziomu jednonienasyconych kwasów thuszczowych. Stwicrdzono również wzrost $(\mathrm{P}<0,05 ; \mathrm{P}<0,01)$ sumy PUFA i MUFA, przy dodatku oleju lnianego lub oleju rzepakowcgo do paszy. Poziom kwasu stcarynowego w mleku owiec otrzymujących dawkę z. dodatkiem $8 \%$ oleju Inianego był najniższy $(\mathrm{P}<0,01)$, natomiast po dodaniu do pasz $10 \%$ oleju lnianego lub 8 i $10 \%$ oleju rzepakowego poziom tego kwasu był istotne wyźszy $(\mathrm{P}<0,05)$ niż u owiec pozostałych grup. Dodatek tłuszczu pochodzenia roślinnego do dawki dla owiec mlecznych zwiększa nie tylko poziom energii w dawce, ale także modyfikuje korzystnie skład kwasów thuszczowych w mleku. 